\begin{tabular}{|l|l|l||}
\hline \multicolumn{2}{|c|}{ PublisherInfo } \\
\hline \hline PublisherName & $:$ & BioMed Central \\
\hline \hline PublisherLocation & $:$ & London \\
\hline \hline PublisherImprintName & $:$ & BioMed Central \\
\hline \hline
\end{tabular}

\title{
The Euroethics database
}

\begin{tabular}{|l|c|l||}
\hline \multicolumn{2}{|c||}{ ArticleInfo } \\
\hline \hline ArticleID & $:$ & 4289 \\
\hline \hline ArticleDOI & $:$ & $10.1186 /$ ccf-2000-webreport1643 \\
\hline \hline ArticleCitationID & $:$ & webreport1643 \\
\hline \hline ArticleSequenceNumber & $:$ & 30 \\
\hline \hline ArticleCategory & $:$ & Web report \\
\hline \hline ArticleFirstPage & $:$ & 1 \\
\hline \hline ArticleLastPage & $:$ & 3 \\
\hline \hline & & RegistrationDate : 2000-12-9 \\
\hline ArticleHistory & $:$ & OnlineDate \\
\hline \hline ArticleCopyright & $:$ & Current Science Ltd2000-12-9 \\
\hline \hline ArticleGrants & $:$ & \\
\hline \hline ArticleContext & $:$ & 1305444 \\
\hline \hline
\end{tabular}




\section{Background}

It would seem that the European intensivist who turns to the internet for a source of information about ethical dilemmas, will find it quite difficult to find any useful resources. A quick search on Google.com, using the terms 'critical care' and 'ethics', produces 147,000 pages, most of which are either adverts for books, or information about courses being held at various American universities. Euroethics is a resource site, however, that aims to serve the needs of intensivists across mainland Europe.

\section{The site}

The site is a collaboration between the Academy for Ethics in Medicine (Germany), INSERM (France) the Katholieke Universiteit Niymegen (Netherlands) and the Swedish Institute for Health Services Development. It is supported by the European Commission. There are three basic sections to the site:

1) an email discussion forum (details are provided on how to subscribe).

2) a basic collection of document resources such as professional codes of practise from the participating countries, covering various issues.

3) The Euroethics database.

\section{The database}

The database covers some 305 journals (mostly non-English) and 4,500 articles. It can be searched in a conventional manner (author name/journal citation, etc) or by 'menu guided search' which is essentially a way of browsing the database by keyword. The aims of the collaborating partners are admirable; to provide a cross-linked depository of resources based on the centralised collections of the participating countries.

The site itself lacks the sophistication of many websites, but the database would appear to be a genuinely useful resource for anyone searching for papers written in German, French, Swedish or Flemish. The site is not helpful if you cannot translate the results into your own language. 


\section{Evaluation}

No special requirements

\section{References}

1. Euroethics. [http://www.gwdg.de/ uelsner/euroeth.htm]

This PDF file was created after publication. 